\title{
The influence of the demographic structure on the economic growth of Ukraine
}

\author{
Nazarii Kukhara
}

\begin{abstract}
The national economy is closely related to the demographic structure of the society. Therefore, in the face of demographic changes, it is necessary to assess the influence of these changes on economic growth. This article presents an estimation of the impact that the future changes in the demographic structure will have on the economic growth of Ukraine, represented by the rate of changes in GDP per capita. The decomposition of GDP per capita and making the components of this decomposition dependent on the demographic structure allowed an empirical analysis, which used a variety of econometric and statistical techniques and was based on a population forecast prepared by the Ptoukha Institute for Demography and Social Studies of the National Academy of Sciences of Ukraine. As a result, it was determined that the impact of the changes in the demographic structure on Ukraine's long-term economic growth will be highly diverse over the studied period (until 2060). However, considering the entire period of the analysis, the negative effects of the changes in the demographic structure on the economy will be counterbalanced by the positive effects of these changes.
\end{abstract}

Keywords: GDP per capita, demographic determinants of growth, demographic structure, Ukraine

JEL: C53, E17, J11

\section{Introduction}

The population, its prosperity and social development is the defining feature of a society and constitutes the basis of a state's power. Therefore, the demographic situation has always remained the object of attention of a wide range of stakeholders, including the scientific community. Scientific disciplines are interested in a variety of issues relating to demographics, particularly its impact on different economic and social aspects.

Economists argue that economic conditions affect only the flows of demographic processes (e.g. fertility, life expectancy), which remains insignificant in relation to the demographic structure in the short term. On the other hand, the impact of the demographic conditions on economic processes is immediate and significant (Wasilewska \& Pietrych, 2018). There are many channels through which demographic changes affect the economy, but the following are most often distinguished: investments, the labour market and productivity.

In the macroeconomic perspective, demographic issues are studied in the context of economic growth. Demographic conditions have a direct impact on real GDP as they determine the size of the labour force (Jong-Won et al., 2014), which, in turn, is

\footnotetext{
a Jagiellonian University in Kraków, ul. Gołębia 24, 31-007 Kraków, Poland, e-mail: nazarii.kukhar@doctoral.uj.edu.pl, ORCID: https://orcid.org/0000-0003-0329-9215.
} 
the central factor of production. Thus, the increase in the labour force resulting from the growth of the working age population, directly contributes to the increase in production (Florczak \& Przybyliński, 2016). Conversely, a declining population entails a slower output growth, unless it is compensated by an increase in labour productivity. When the productivity level is constant, GDP drops proportionally to the number of workers (Coleman \& Rowthorn, 2011).

However, the research results presented in the literature show that the influence of demographic conditions on economic growth is ambiguous. Depending on the economic and social characteristics, and on the development level of individual countries, demographic changes may either accelerate or slow down economic growth, although their impact may as well be neutral (Mączyńska, 2010).

Despite the expected severe economic consequences, demographic change usually remains outside the scope of many macroeconomic policy discussions and debates. For example, most economic growth models assume that population grows at a steady pace, and many business cycle models set the size of the population at a fixed level when analysing aggregate demand (Jong-Won et al., 2014).

Demographic changes are one of the most significant long-term challenges that will have a profound impact on the economy of European countries. The working age population is declining rapidly and this process is expected to continue in the future. The per capita income of most Central and Eastern European countries is still below that of Western European countries, putting the former at risk of 'aging before becoming rich' (Batog et al., 2019).

Ukraine is more vulnerable to the negative effects of aging and population decline than many other regions in Europe. A constant downward trend has been observed in this respect ever since Ukraine regained independence. Along with the decline of the whole population of the country, the working age population is also decreasing. Moreover, taking into account the increasing pace of aging, not only an absolute, but also a relative decrease in the number of working population in the overall structure of the Ukrainian population is noted (Kudlak, 2019).

Ukraine is still going through economic, political, and social transformations caused by the collapse of the Soviet Union. In this situation, an aging society poses additional challenges (e.g. maintaining and improving living standards and productivity), which are particularly dangerous, as Ukraine (and other countries in a similar situation) already struggles with underdeveloped institutions, structural weaknesses, a vulnerable economy, and political instability. In addition, compared to higher-income countries, Ukraine has access to fewer financial resources essential to mitigating the negative effects of an aging society (Kupets, 2014). The situation on the Ukrainian labour market is also difficult - the ratio between labour demand and supply fell in all groups of occupations, particularly among those that do not require 
special training or highly-qualified workers. The most pressing problem is the imbalance between the qualifications and work experience required by employers and the skills and professional experience of those seeking jobs (Stoychik, 2018). Along with this, regional labour market indicators tend to deteriorate. There are regions which are characterised by a critically high number of registered unemployed per one vacancy (Zoidze, 2013). Moreover, almost one-third of the total employed population and more than $25 \%$ of those who are actively seeking work are concentrated in five regions (out of 25) (Cymbal \& Iarosh, 2020).

The aging of the population in Ukraine is mainly the effect of a decline in fertility and the continuing emigration of the working age population, not due to an enormous increase in life expectancy as observed in developed countries. Considering the number of emigrants from Ukraine, Poland has traditionally taken the leading position in the recent years (Kudlak, 2019). Thus, the results of research on the impact of the changes in demographic conditions on economic processes in Ukraine could also be interesting for Poland.

There are numerous publications in the literature describing the influence of demographic factors on the economic development of various countries. However, it should be noted that in relation to Ukraine, these publications are in most cases limited to the analysis of the general demographic trends and problems, and include only theoretical considerations of the effect demographic conditions have on the economy (Aksonova, 2012; Geyets, 2011; Romanukha, 2016), while only a few studies provide an empirical assessment of this impact.

A study published by the World Bank entitled 'Golden Aging' describes the current demographic situation in Europe and Central Asia (including Ukraine). The expected demographic conditions which are based on a population forecast prepared by the United Nations (UN) are also presented. Considering this forecast, the authors indicate the increasing aging process of the population in the aforementioned regions and, by using the dynamic overlapping generations (OLG) model, determine how this process affects individual countries (Bussolo et al., 2015). The findings are presented below:

- according to the report, due to the aging of the societies of Eastern European countries, a workforce reduction amounting to a total of nearly 30 million people should be expected by 2050 ;

- the aging of the society will not necessarily reduce the per capita income. The authors indicate that even if an increasing dependency ratio is observed, GDP per capita may also increase;

- the average age of the workforce in these regions will increase, and yet the average labour productivity will not necessarily decrease;

- as the life expectancy in these regions increases, so will the savings rate. 
In a publication entitled 'Demographic Headwinds in Central and Eastern Europe' of the International Monetary Fund (IMF), as well as in a study prepared by the World Bank, the authors look at the demographic pressure in the countries of Central, Eastern and North-Eeastern Europe (including Ukraine) and make an attempt to determine the macroeconomic implications of these demographic trends. According to the authors, demographic changes will trigger the following effects (Batog et al., 2019):

- most countries will experience a significant decline in the workforce by 2050, especially in Ukraine, where this decline will exceed 30\% (compared to 2015);

- the aging of the population is likely to entail an increase in expenditure on health care and pensions, in most cases by more than 5\% of GDP, and with regard to Ukraine, this increase will reach approximately 10\% of GDP (compared to 2015);

- the increase in the average age of the labour force will be related to a decrease in total labour productivity and total factor productivity. In Ukraine the average annual decline in total factor productivity will reach up to $0.6 \%$ in the period of 2020-2050;

- the demographic changes will result in an average slowdown of the economic growth by 0.6 percentage points per year in 2020-2050. Ukraine will experience the impact of these changes slightly stronger, as they are likely to cause an annual average decline in GDP per capita of about $0.8 \%$.

Kupets (2014) reviews the general demographic trends in Ukraine and analyses the impact of demographic changes on the labour market, particularly on the supply of the labour force and labour productivity. Based on the forecast of the population prepared by the UN, the author argues that, even considering a very optimistic scenario of demographic development, the Ukrainian economy is bound to face a significant reduction in labour force by 2060 . However, Kupets also claims that the introduction of substantial improvements in the area of labour and technology productivity is likely to mitigate the negative effects of the demographic changes in the Ukrainian economy. The author argues that if the rate of the increase in labour productivity remains at the level of $0.5 \%$ per year, the annual rate of change in GDP per capita will be unaffected by the changes in demographic conditions.

Rovný et al. (2021) used Pearson's correlation to examine the strength of relationships between selected economic and demographic indicators. The results of this analysis demonstrate that the per capita income is quite strongly correlated with the labour force aged 35-54. On the other hand, a strong positive correlation was found between unemployment and the population aged 0-14 and the elder workforce aged 55-65. Moreover, a very strong negative correlation was also observed between unemployment and the young working population aged 15-34. 
In her work, Maksymenko (2009) identifies the mutual channels of influence between fertility and the economy. The author used a vector autoregressive model to determine the short- and long-term responses of fertility to the unemployment rate, the households' level of available financial resources, and economic growth. Maksymenko's research shows that changes in the unemployment rate and the amount of the households' available means explain more than one-third of the variability in fertility.

The current studies, in particular those conducted by the World Bank and the IMF provide a solid analysis of the influence that demographic changes have on economic growth; however, the studies fail to take into account all the main channels of this impact (such as investment or human capital). In result, there is a considerable research gap in terms of the empirical assessment of the impact of demographic conditions on the economy of Ukraine.

Thus, the aim of this work is to present an empirical analysis of the impact of changes in the demographic structure on Ukraine's long-term economic growth in the years 2017-2060 by means of selected econometric techniques (including general equilibrium models, shift-share methods, as well as statistical and econometric methods) suggested by Florczak (2017). The empirical results presented in this article provide information about the scale of the potential long-term changes in the dynamics of GDP per capita caused by changes in the demographic structure of the Ukrainian population. The empirical research is based on the medium variant of Ukraine's demographic development forecast until 2060, prepared by the Ptoukha Institute for Demography and Social Studies of the National Academy of Sciences of Ukraine (2014), referred to as IDBSNAN. In the process of constructing the population forecast, such components as fertility, life expectancy and net migration were taken into account.

\section{Influence of the demographic structure of Ukraine's society on economic growth}

The starting point for the empirical analysis is the decomposition of the influence of the demographic structure on GDP per capita (Landmann, 2004; see also Florczak, 2008a):

where

$$
G D P C_{t} \equiv G D P H_{t} \cdot A W H_{t} \cdot R E L F_{t} \cdot R W A P_{t},
$$

$G D P C_{t}=\mathrm{GDP} / \mathrm{N}-\mathrm{GDP}$ per capita, where $\mathrm{N}$ is the population;

$G D P H_{t}=\mathrm{GDP} /$ working hours - productivity per hour;

$A W H_{t}$ = working hours / number of employed persons - number of working hours per one employee; 
$R E L F_{t}=$ number of employed persons / number of working age persons - effective employment ratio;

$R W A P_{t}=$ number of working age persons / total population - population age structure.

By transforming equation (1) from the form reflecting the levels of all components of a given equation to the form showing changes in the growth rate of all components of equation (1), we receive the following formula:

$$
G \dot{P P C} C_{t} \equiv G \dot{P P} H_{t}+A \dot{W} H_{t}+R \dot{E} L F_{t}+R \dot{W} A P_{t},
$$

where the dot above the component symbol indicates the growth rate $\left(\dot{a}_{t}=\frac{a_{t}-a_{t-1}}{a_{t-1}}\right)$.

Equation (2) shows that economic growth, approximated by the GDP per capita growth rate, is defined by both economic and demographic conditions. Moreover, the strength of the impact of the growth rate changes of all explanatory variables in equation (2) on the dependent variable is the same and amounts to one to one.

Due to the fact that the aim of the paper is to estimate the influence of only the demographic factors on long-term economic growth, and because variable $A W H_{t}$ is not directly dependent on demographic conditions, the value of $A W H_{t}$ was fixed at the level noted in 2017 (Florczak et al., 2018). The subsequent parts of the article present the development of all the components of equation (2).

\subsection{Development of the age structure and the share of employed persons in the working age population in the years 2017-2060}

Figure 1 presents the values of the age structure during the analysed period, while Figure 2 demonstrates the annual growth rate for this variable. Due to the fall in the value of the age structure coefficients, a decrease in the level of GDP per capita should also be expected in the analysed years. The age structure coefficient will decrease by a seventh, from a level slightly exceeding 0.68 to somewhat below 0.59 within 2017-2060, which corresponds to the average annual decrease in GDP per capita in this period by nearly 0.36 percentage points. 
Figure 1. Age structure coefficient (RWAP)

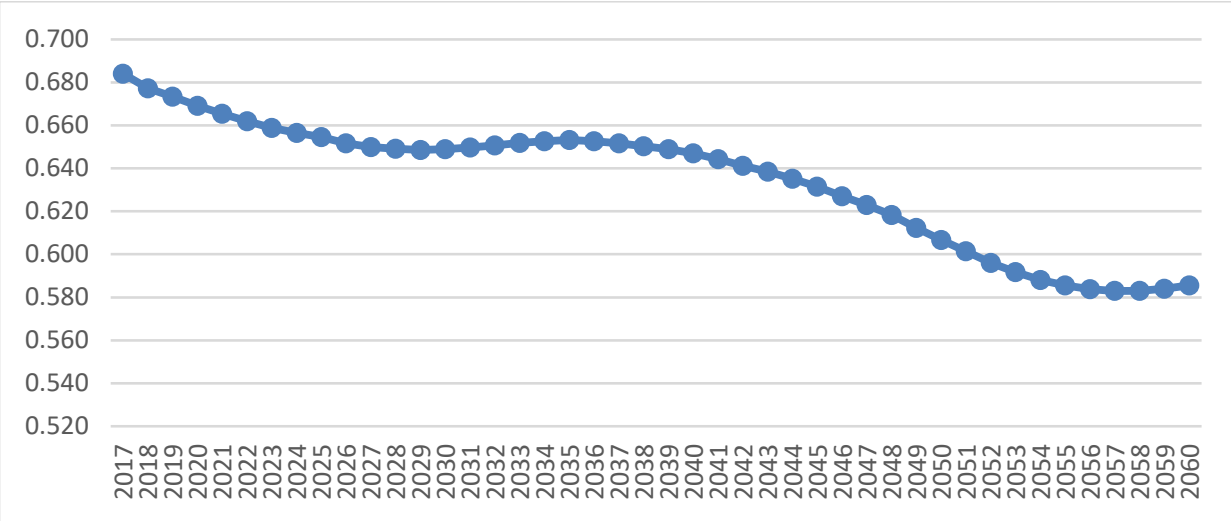

Source: author's calculations based on State Statistics Service of Ukraine (SSSU) data (number of working age persons, total population) and IDBSNAN forecasts (number of working age persons, total population).

Figure 2. Annual growth rates of the RWAP

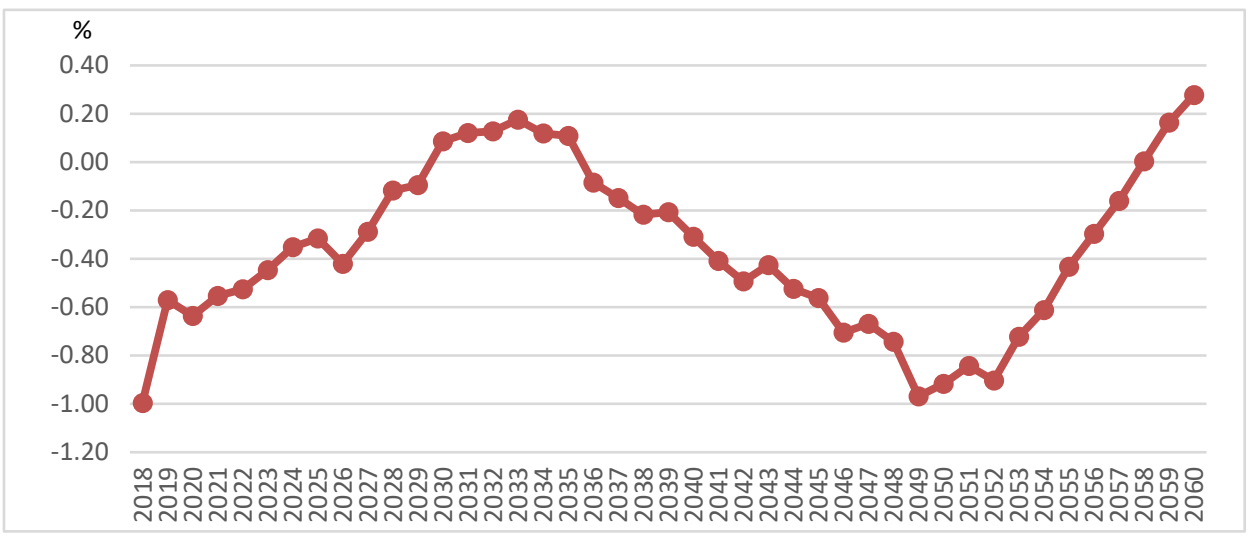

Source: author's calculations based on SSSU data (number of working age persons, total population) and IDBSNAN forecasts (number of working age persons, total population).

As Figures 1 and 2 suggest, the development of RWAP is unevenly distributed over time. Until the beginning of the 2030s, a declining negative impact of this factor is observed, whereas in the years 2030-2035 this influence will be even positive with an average annual increase of nearly $0.12 \%$. However, starting from the mid-2030s until the early 2050s, the increasingly unfavourable impact of this component on economic growth should be taken into account. In the last decade of the analysed period, this negative effect should lessen and changes in the age structure coefficient will contribute to an increase in the level of GDP per capita at the end of the studied period. 
The next component of equation (2) - the effective employment ratio coefficient - is assumed to be constant for individual age groups: 15-19, 20-29, 30-39, 40-49, 50-59, and 60+, i.e. fixed at the level registered in 2017 (see Figure 3). This division is also related to the explanations of the impact of the age structure of employees on the level of total factor productivity presented in the subsequent parts of this article.

Figure 3. Coefficients of effective employment in Ukraine in 2017 and in the subsequent years of the analysis (by age groups)

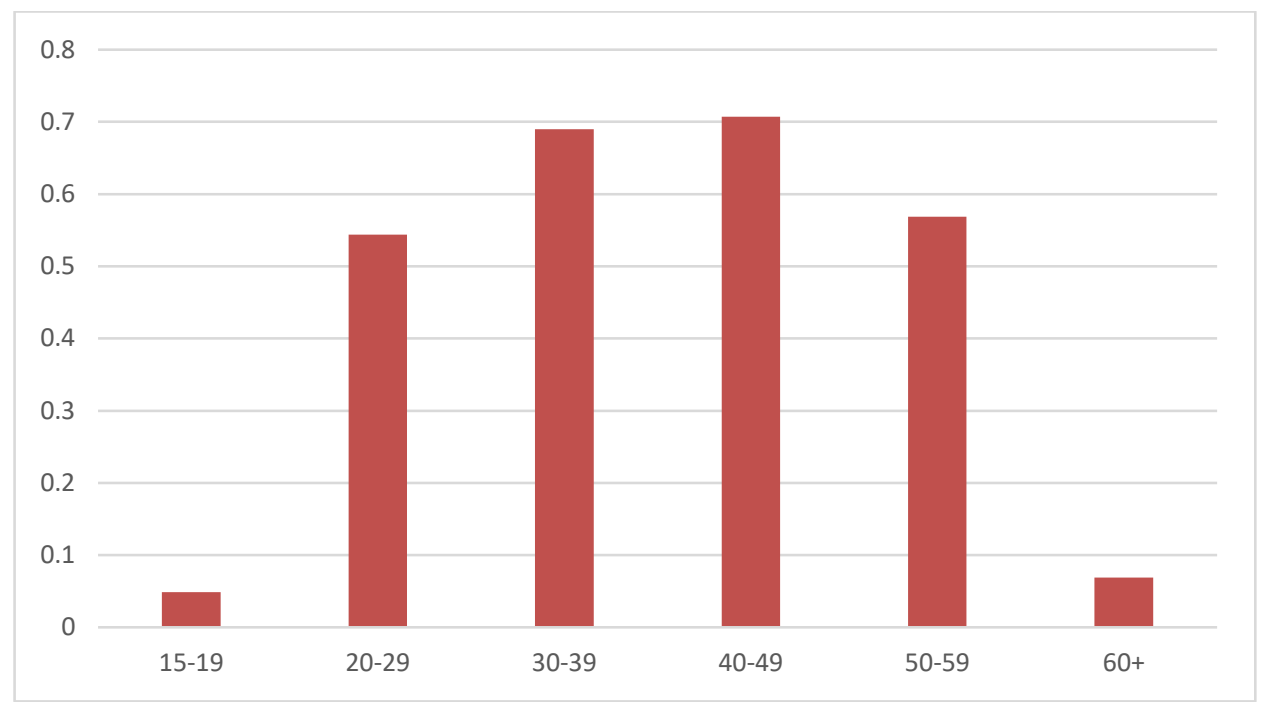

Source: author's calculations based on SSSU data (total population, number of working age persons) and the International Labour Organization (ILO) data (number of employed persons) (ILO, n.d.).

Although the effective employment coefficients are constant for individual age groups, it will not be so in the case of the aggregate indicator due to the changes in the demographic structure of the population as seen in Figure 4. Figures 5 and 6 present the development of the effective employment rate in the analysed period. 
Figure 4. Share of employees by age groups in the total number of employees resulting from the changes in the demographic structure of the population of Ukraine

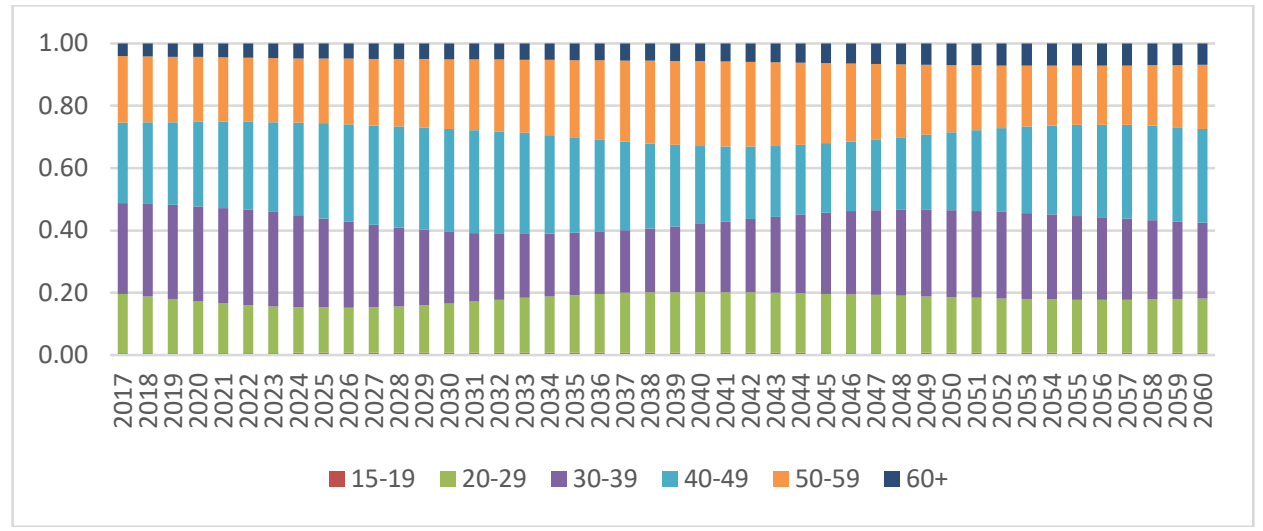

Source: author's calculations based on SSSU data (number of working age persons, total population) and the IDBSNAN forecast (number of working age persons, total population) and assumptions made regarding the effective employment coefficients in individual age groups.

The analysis proves that changes in the effective employment rate caused by changes in the demographic structure of the population will have a diverse impact on the rate of change in GDP per capita at different times. Until the first half of the 2020s, this influence will be negative, while in the second half of the 2020s it will be negligible - the average annual rate of change will remain below $0.03 \%$. From the early 2030s until 2047, a negative impact of changes in the effective employment ratio will be observed, whereas starting from 2048, only a positive impact will be recorded, contributing to an increase in GDP per capita of more than $0.5 \%$ in the years 2052-2053. However, at the end of the analysed period, this positive influence is expected to decrease. When comparing the results of the effective employment ratio and the age structure coefficient, it should be noted that throughout the majority of the analysed period, the direction of the impact of these variables on GDP per capita growth remains the same and unfavourable in most cases, whereas in the periods witnessing a different direction of the impact, the strength of the overall effect will also be negative. 
Figure 5. Effective employment rates in Ukraine

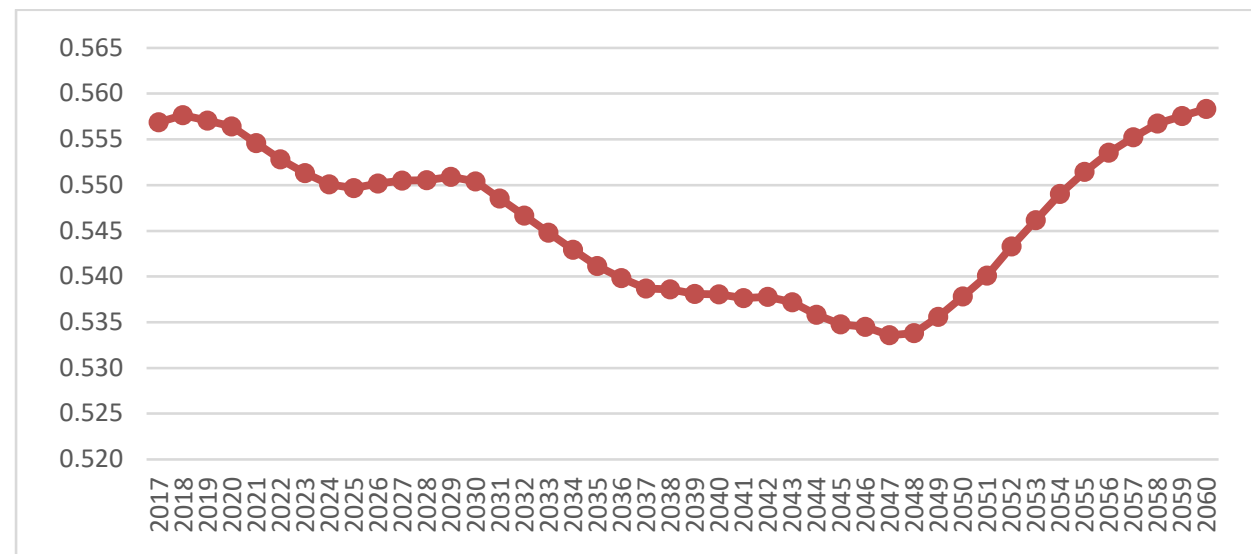

Source: author's calculations based on SSSU data (number of working age persons, total population) and the IDBSNAN forecast (number of working age persons, total population) and assumptions made regarding the effective employment coefficients in individual age groups.

Figure 6. Annual changes in the growth rate of effective employment rates caused by the demographic structure of the population of Ukraine

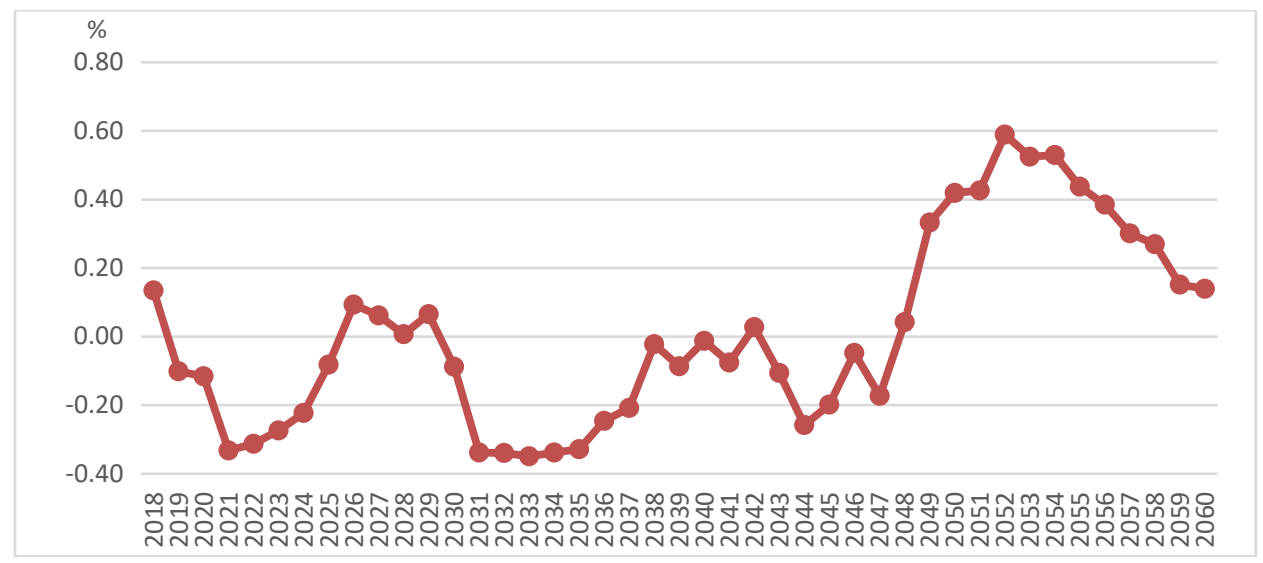

Source: author's calculations based on SSSU data (number of working age persons, total population) and the IDBSNAN forecast (number of working age persons, total population) and assumptions made regarding the effective employment coefficients in individual age groups.

\subsection{Demographic structure and labour productivity in the years 2017-2060}

Labour productivity is central to long-term economic growth and largely dependent on the demographic structure. This component is described using the labour productivity model obtained through the transformation of the Cobb-Douglas production function with constant returns to scale (Feyrer, 2007): 


$$
Y_{t}=K_{t}^{a} \cdot\left(T F P_{t} \cdot N_{t} \cdot h_{t}\right)^{1-a},
$$

where

$Y_{t} \quad-$ GDP in period $t$

$K_{t} \quad$ - fixed assets in period $t$;

$T F P_{t}$ - total factor productivity in period $t$;

$N_{t} \quad$ - number of employees in period $t$;

$h_{t} \quad$ - human capital per employee in period $t$;

a - productivity of fixed assets (many researchers assume that the value of this component equals 0.3) (Florczak et al., 2018).

Equation (3), after undergoing a two-sided division by the number of employees, takes the following form of the labour productivity function:

$$
y_{t}=k_{t}^{a} \cdot\left(T F P_{t} \cdot h_{t}\right)^{1-a}
$$

where

$y_{t}$ - labour productivity in period $t$;

$k_{t}$ - fixed assets per employee in period $t$ - technical equipment of work.

The technical equipment of work in function (4) can be converted into capital intensity, which will allow the identification of all the channels of the influence of the demographic conditions on labour productivity. Thus, the productivity function will take the following form:

$$
y_{t}=\left(\frac{K}{Y}\right)_{t}^{\frac{a}{1-a}} \cdot T F P_{t} \cdot h_{t}
$$

where

$\frac{K}{Y}$ - capital intensity in period $t$.

Thus, the labour productivity function encompasses three factors: human capital, total factor productivity, and technical equipment of work or capital intensity. The impact of human capital and total factor productivity on labour productivity, and thus on economic growth, is the same and equals one to one. Therefore, a change of either of these two factors by $1 \%$ will also change the level of GDP per capita by $1 \%$. On the other hand, a change in the technical equipment of work by one percentage point will contribute to a change in GDP per capita by a percentage point. In the case 
of capital intensity, however, a change in this component by $1 \%$ will result in a change in GDP per capita by $a /(1-a)$ percentage points.

\subsubsection{Human capital and labour productivity}

Human capital is understood as all psychophysical features of an individual, such as their abilities and skills, education, knowledge, work experience, health condition, cultural level, etc., which have an impact on the productivity of work and which are inseparably connected with the human being as the holder of these values (Florczak, 2008 b). However, when determining the level of human capital, especially in the macro scale, it is not possible to include all the above-mentioned features. For this reason, in most cases empirical research takes into account only a few of them, usually the level of education, work experience, and health conditions (Wößmann, 2003).

There are several methods of quantifying the level of human capital, the most common of which is based on the extended Mincer equation. This particular method quantifies human capital taking into account its main components, i.e. the level of education, work experience, and health conditions. It takes the form of the following equation (Florczak, 2017):

$$
H C_{t}=\left[\left(1.433329 \cdot E M_{t} \cdot L E B M_{t}+E F_{t} \cdot L E B F_{t}\right) \cdot H C E_{t} \cdot E E_{t}\right] / T E_{t}
$$

where

$H C_{t} \quad$ - human capital in period $t$;

$E M_{t} \quad$ - number of employed men in period $t$;

$E F_{t} \quad$ - number of employed women in period $t$;

$L E B M_{t}-$ male life expectancy at birth in period $t$;

$L E B F_{t}$ - female life expectancy at birth in period $t$;

$T E_{t} \quad-$ total number of employees in period $t$;

$H C E_{t}$ - human capital per employee, taking into account education in period $t$ :

$$
H C E_{t}=\frac{1.055274 \cdot E H E_{t}+E S E_{t}+E B E_{t}}{T E_{t}}
$$

where

$E H E_{t}$ - number of the employed with higher education in period $t$;

$E S E_{t}$ - number of the employed with secondary education in period $t$;

$E B E_{t}$ - number of the employed with basic education in period $t$;

$E E_{t} \quad$ - work experience sub-index in period $t$ : 


$$
E E_{t}=\sum_{i=15}^{69}\left[\frac{N_{i t}}{T E_{t}} \cdot \frac{\exp \left(0.0228 \cdot E_{i}-0.000565 \cdot E_{i}{ }^{2}\right.}{\exp \left(0.0228 \cdot E_{15}-0.000565 \cdot E_{15}{ }^{2}\right.}\right]
$$

where

$N_{i t}$ - number of the employed at the age of $i$ and in time period $t$,

$E_{i}$ - work experience of the employee in the age of $i$ (calculated as follows: employee experience $=$ employee age - number of years of education -5$)$.

The individual weights used in equations (6), (7) and (8) should be estimated using a representative microeconomic sample based on survey data. Since only a few studies meet this requirement, the relevant estimates were drawn from the results of a study conducted by Vakhitova \& Coupe (2013), which is the most recent one in this area.

Thus, to determine the level of human capital in the analysed period, it is necessary to have information on the following: life expectancy at birth by gender (see Figure 7), the employees' education structure (this structure was fixed at the level observed in 2017), the number of years of work experience of a working person (assumed to be fixed at the level registered in 2017 for a particular age of the employees), the share of the employed men and women in the total number of employed persons (fixed at the level observed in 2017), the share of employed persons by individual age groups in the total number of employed persons (for the results of the analysis on the effective employment rate, see Figure 4). ${ }^{1}$

Since the stability of the structure of education was assumed in the analysed period, the HCE sub-index (formula (7)) remains unchanged, and fluctuations of the level of human capital are caused by changes in the health condition of the society (the expected life expectancy of the newly-born) and changes in the sub-index of work experience. The development of the $E E$ sub-index, normalised according to the 2017 level, is presented in Figure 8, while the levels of human capital, also normalised according to the 2017 level are presented in Figure 9. Figures 10 and 11 show the pace of changes of these indicators and Figure 11 presents the impact of the changes in human capital on economic growth.

\footnotetext{
${ }^{1}$ Setting some values at a constant level is necessary to meet the ceteris paribus principle with regard to the impact of demographic changes on economic growth.
} 
Figure 7. Life expectancy of men and women in Ukraine

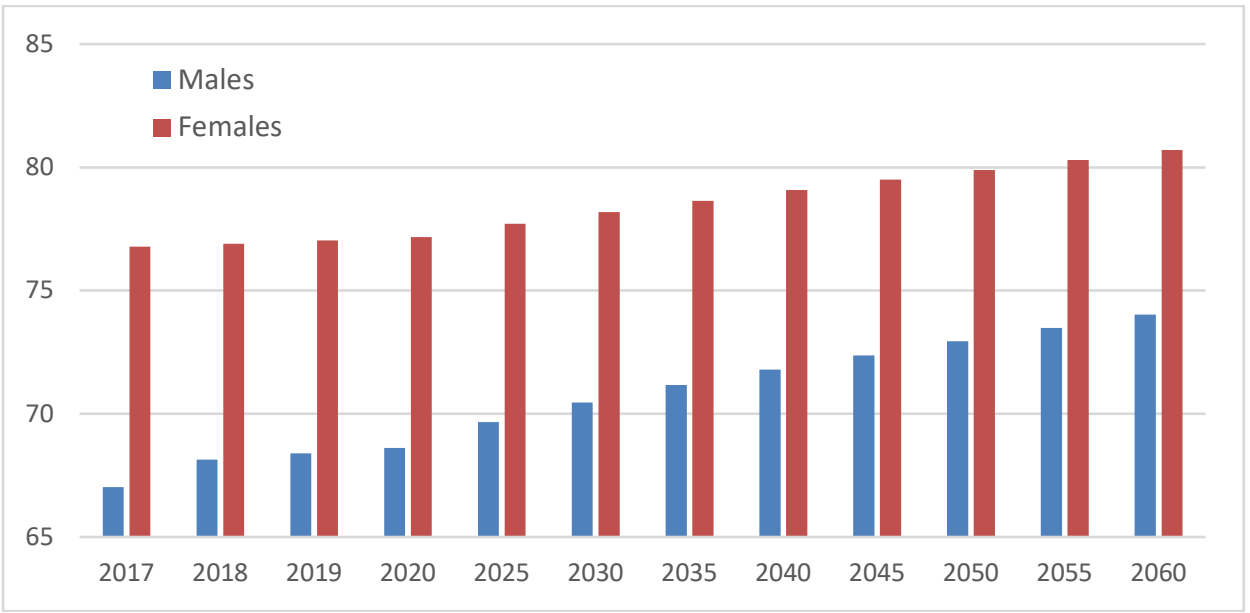

Source: author's work based on IDBSNAN forecasts (life expectancy at birth).

Figure 8. Levels of the work experience sub-index

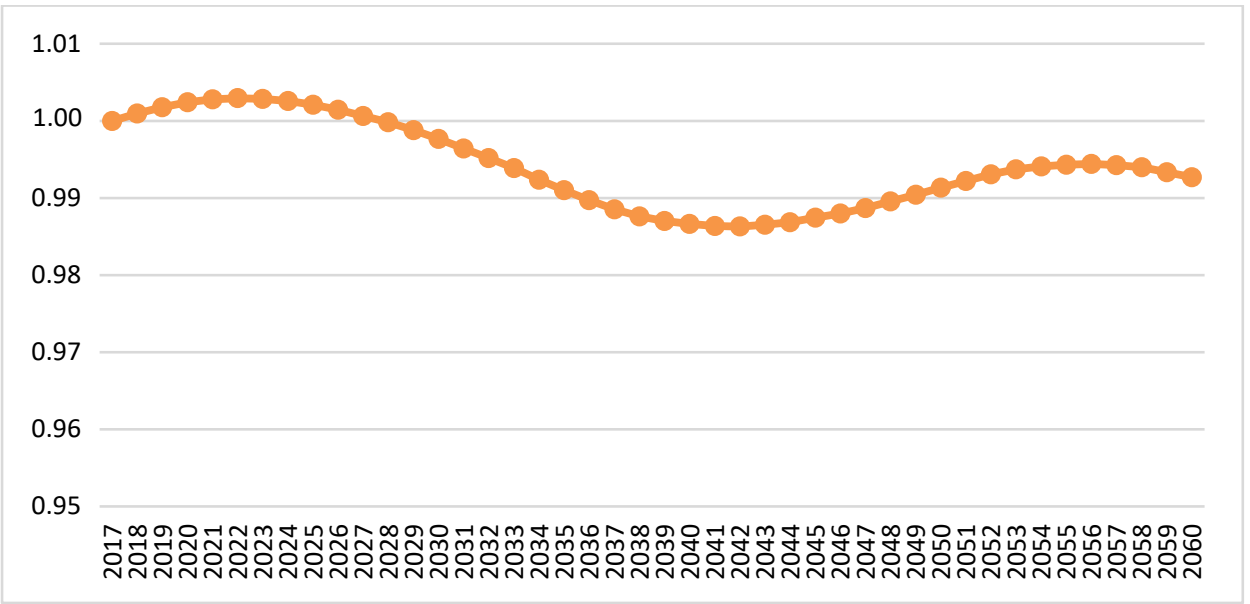

Source: author's calculations based on the SSSU data (number of the employed persons, education, number of working age persons), ILO data (number of employed persons, education) (ILO, n.d.) and the IDBSNAN forecast (number of working age persons).

Figures 8 and 9 demonstrate that by 2060 long-term demographic changes in Ukraine will contribute to an increase in the level of human capital by almost oneeighth compared to 2017, which corresponds to its average annual growth of nearly $0.17 \%$. On the other hand, the work experience sub-index will slightly change due to the occurring demographic changes. 
Figure 9. Levels of human capital

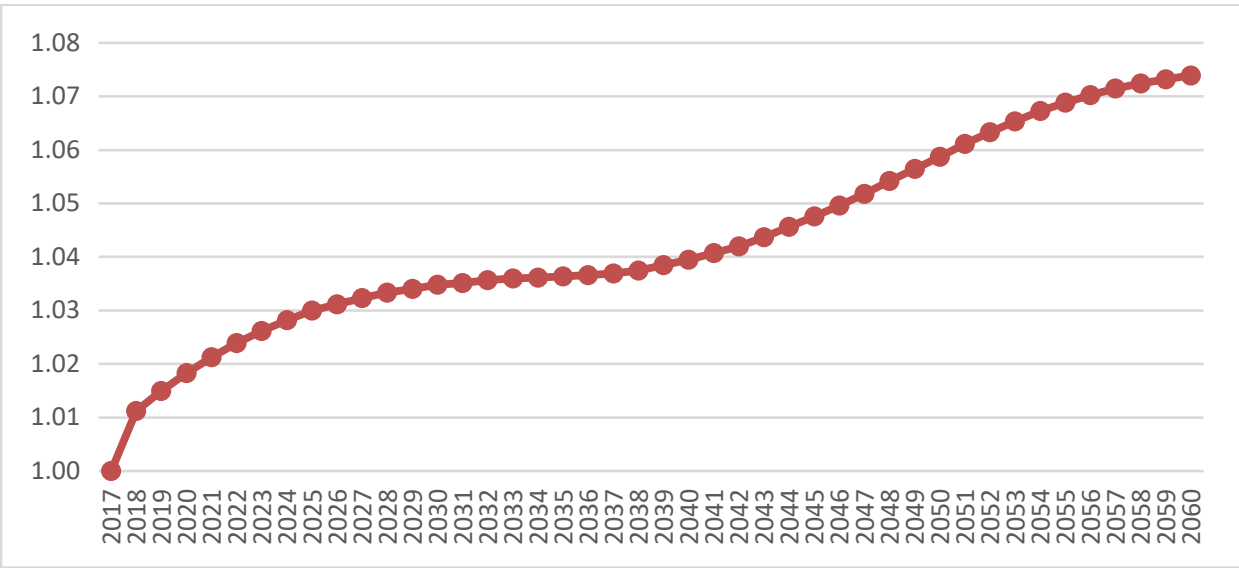

Source: author's calculations based on the SSSU data (number of the employed persons, education, number of working age persons, life expectancy at birth), ILO data (number of employed persons, education) (ILO, n.d.) and the IDBSNAN forecast (number of working age persons, life expectancy at birth).

Figure 10. Changes in the growth rate of the work experience sub-index

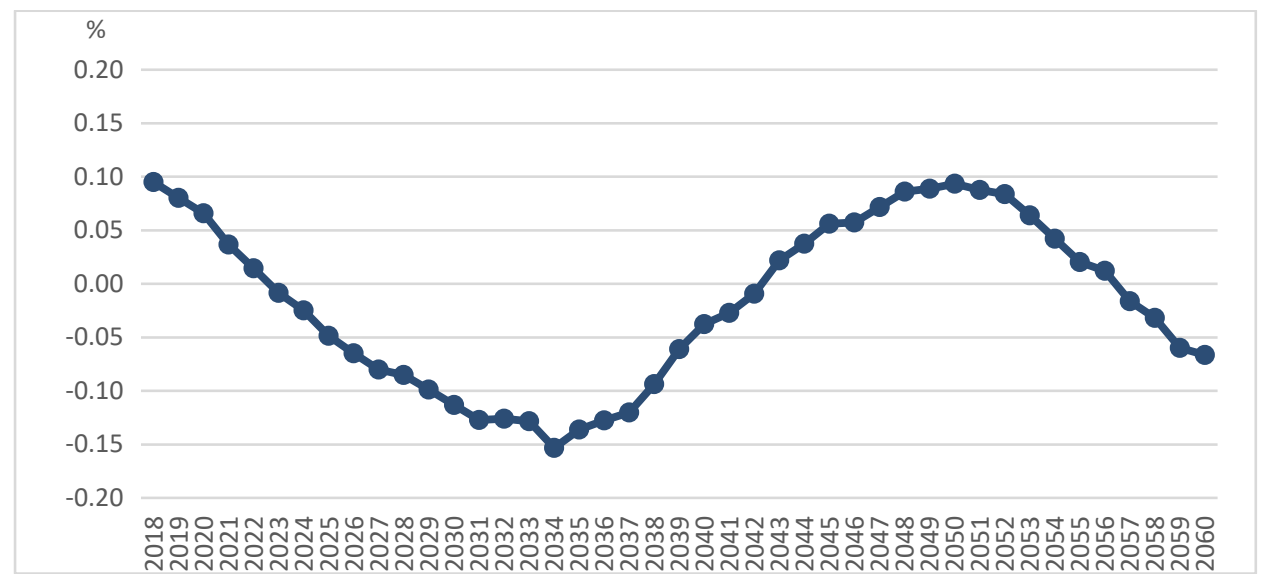

Source: author's calculations based on the SSSU data (number of employed persons, education, number of working age persons), ILO data (number of employed persons, education) (ILO, n.d.) and the IDBSNAN forecast (number of working age persons). 
Figure 11. Changes in the growth rate of human capital

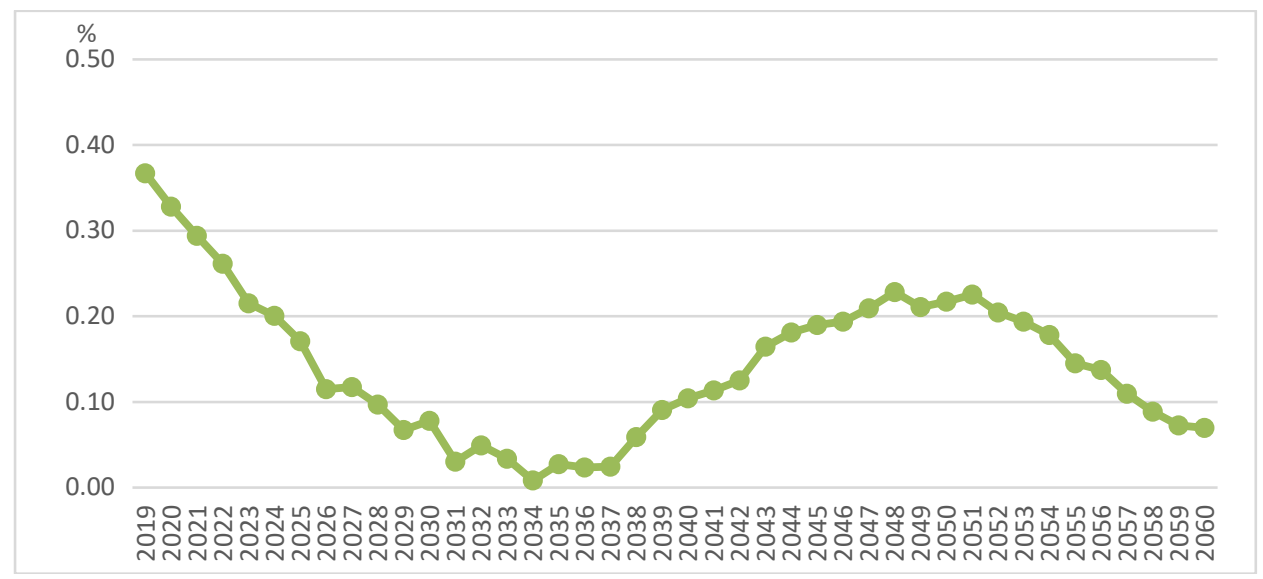

Source: author's calculations based on the SSSU data (number of the employed persons, education, number of working age persons, life expectancy at birth), ILO data (number of employed persons, education) (ILO, n.d.) and the IDBSNAN forecast (number of working age persons, life expectancy at birth).

As Figures 10 and 11 suggest, changes in the values of human capital are to a greater extent caused by changes in the health condition of the Ukrainian society, while the impact of changes in the level of the work experience sub-index is negligible. Moreover, the impact of changes in human capital (resulting from changes in the demographic conditions in Ukraine) on the growth rate of GDP per capita in the analysed period is positive, although the impact is not evenly distributed over time. Until the mid-2030s, the growth of human capital will slow down, but from the second half of the 2030s it will gradually accelerate until the end of the 2040s, when another slowdown is expected to occur and remain until the end of the studied period.

\subsubsection{Technical equipment of work and labour productivity}

The technical equipment of work component also has an impact on work productivity. The decrease in the total number of people employed, which is a consequence of the fall in the number of Ukraine's population in the analysed period (Kupets, 2014), will result in an autonomous increase in the technical equipment of work factor. In order to assess the impact of demographic changes on the amount of capital per working person in the analysed period, the value of fixed assets was assumed to be of the level noted in 2017. Figure 12 presents the results of this experiment. 
Figure 12. Levels of the technical equipment of work component resulting from changes in the demographic structure of the population of Ukraine (in millions of Ukrainian hryvnias (UAH), at 2017 prices)

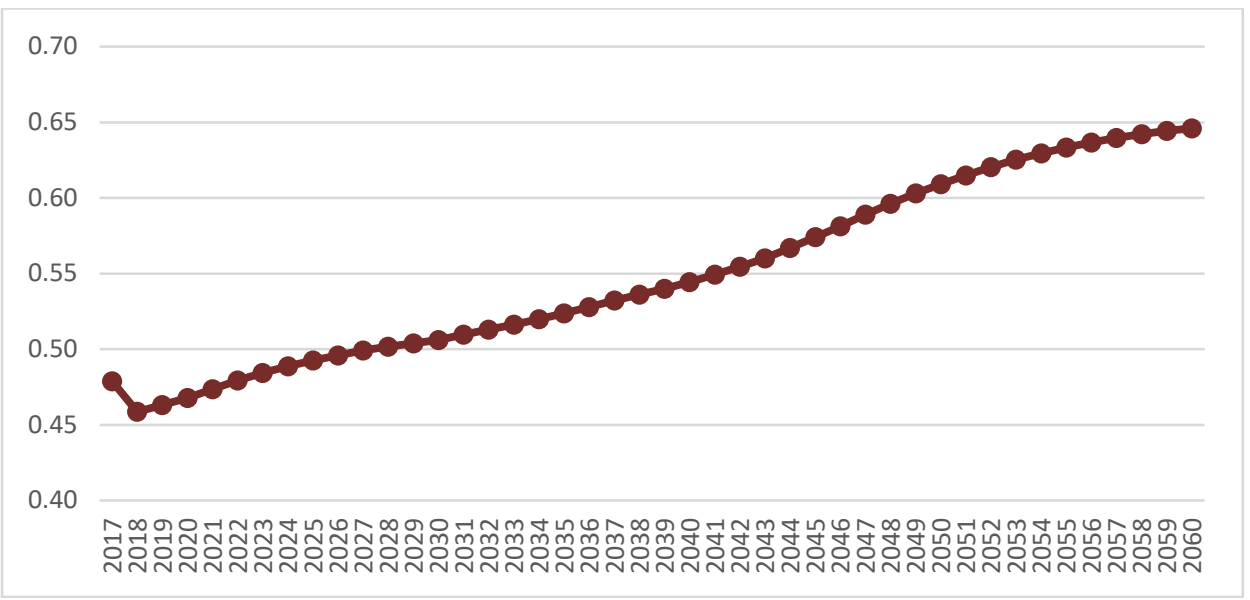

Source: author's calculations based on the SSSU data (fixed assets, number of working age persons), ILO data (number of employed persons) (ILO, n.d.) and the IDBSNAN forecast (number of working age persons).

Figure 12 shows that the technical equipment of work will regularly increase (due to the decreasing number of employees and the fixed value of capital). In consequence, the impact of these changes on GDP per capita will be positive. However, this effect may be significantly offset by a decrease in the propensity to invest, resulting from e.g. a reduced tendency of the elderly to accumulate savings (Bloom et al., 2010; Liu et al., 2013). Thus, these circumstances should be taken into account when examining the influence that changes in the demographic structure have on the value of tangible assets. For this purpose, the results of the IMF's research on the impact of demographic changes on various macroeconomic categories were used (Jong-Won et al., 2014). The results from the IMF study confirm the statistically significant and negative impact of the old dependency ratio on the investment rate. A change in the old dependency ratio by $1 \%$ causes, ceteris paribus, a change in the investment rate by $0.332 \%$ in the opposite direction. Figures 13 and 14 present the evolution of the demographic dependency ratio and economic dependency ratio of the elderly in Ukraine in 2017-2060. 
Figure 13. Values of the economic dependency ratio in Ukraine

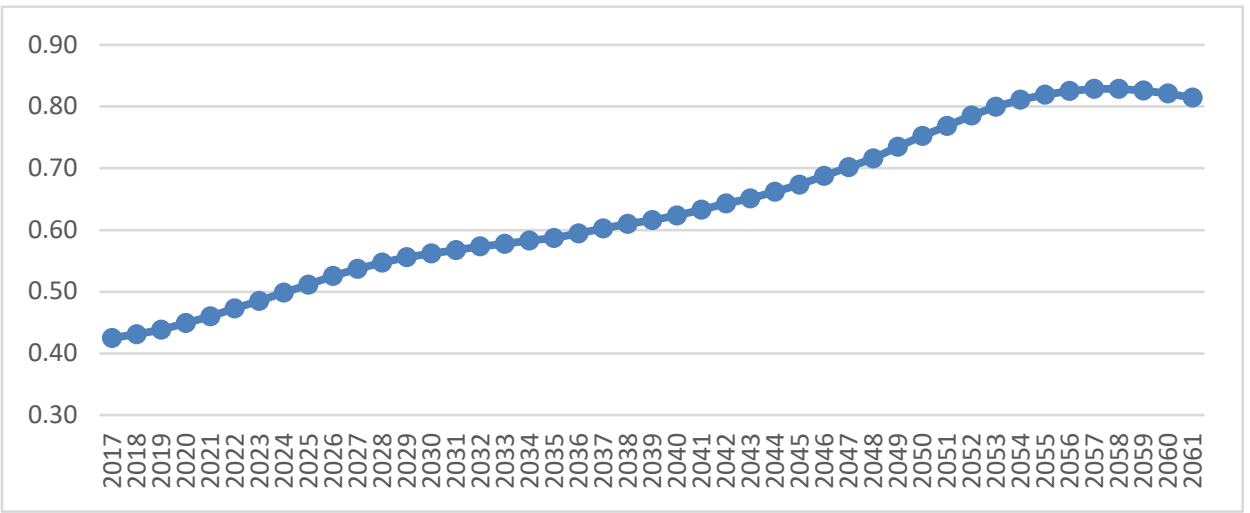

Source: author's calculations based on SSSU data (number of working age persons, total population) and the IDBSNAN forecast (number of working age persons, total population) and assumptions made regarding the effective employment coefficients in individual age groups.

Figure 14. Values of the demographic dependency ratio in Ukraine

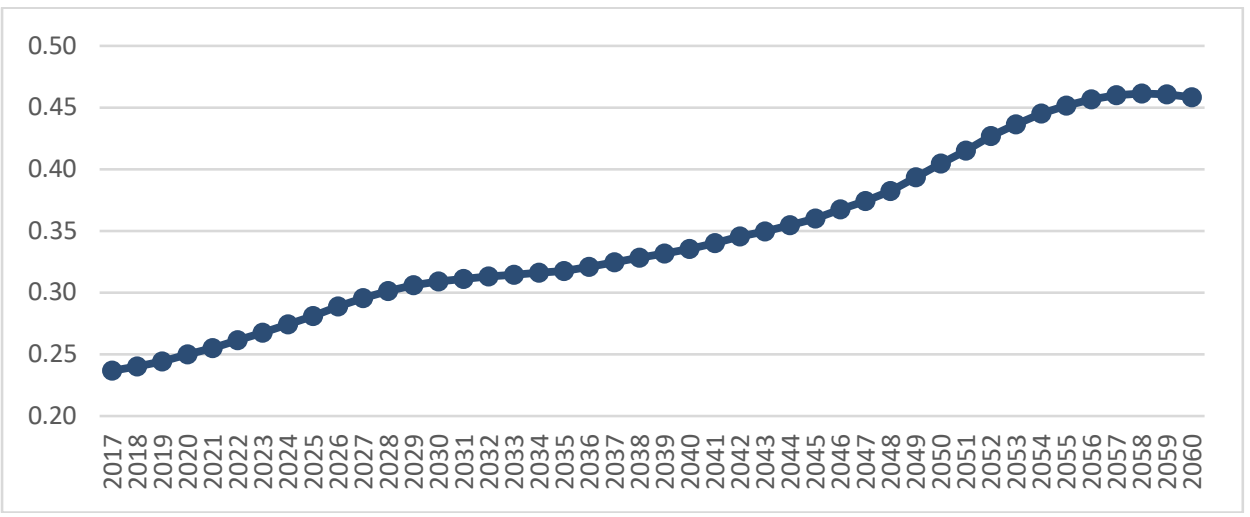

Source: author's calculations based on SSSU data (number of working age persons, total population) and the IDBSNAN forecast (number of working age persons, total population).

Figures 13 and 14 show that the demographic dependency ratio and the economic dependency ratio for people aged $65+$ will almost double in the analysed period. Thus, it will cause unfavourable changes in the propensity to invest and the rate of investment. In order to link the decrease in the investment rate with the amount of tangible assets, the capital accumulation equation was used (Bussolo et al., 2015):

$$
F A_{t}=(1-\delta) \cdot F A_{t-1}+I_{t}
$$


where

$F A_{t}$ - amount of tangible property in period $t$;

$\delta \quad$ - tangible assets depreciation rate;

$I_{t} \quad$ - investment outlays in period $t$.

Using the 2017 value of tangible assets as a reference point and adopting the depreciation rate at the level of $\delta=5 \%$ (Filipowicz \& Tokarski, 2016), the determination of the value of investments guaranteeing the maintenance of the value of tangible assets at a constant level becomes possible. Thus, if the amount of restitution investments is known, then it is possible to determine their share in the GDP, which will allow linking this category with the results of the research of the IMF. It enables the assessment of the impact of the decline in the propensity to invest, resulting from the changes in the demographic structure, on the level of the tangible capital and, at the same time, on the level of the technical equipment of work. Figure 15 shows the development of the amount of the tangible capital per employee caused by the decline in the propensity to invest, while Figure 16 presents the impact of changes of this category on the growth rate of labour productivity.

Figure 15. Amount of technical equipment of work caused by a decline in the propensity to invest, resulting from changes in the demographic structure of the Ukrainian population (in millions of UAH, at 2017 prices)

0.4790

0.4785

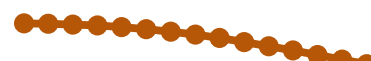

0.4785
0.4775

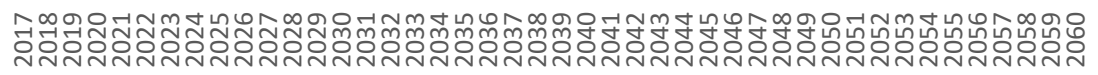

Source: author's calculations based on the SSSU data (fixed assets, number of working age persons, total population), ILO data (number of employed persons) (ILO, n.d.) and the IDBSNAN forecast (number of working age persons, total population). 
Figure 16. Annual changes in the growth rate of labour productivity resulting from changes in the level of technical equipment of work caused by a decrease in the propensity to invest, which is determined by the demographic structure of the population of Ukraine

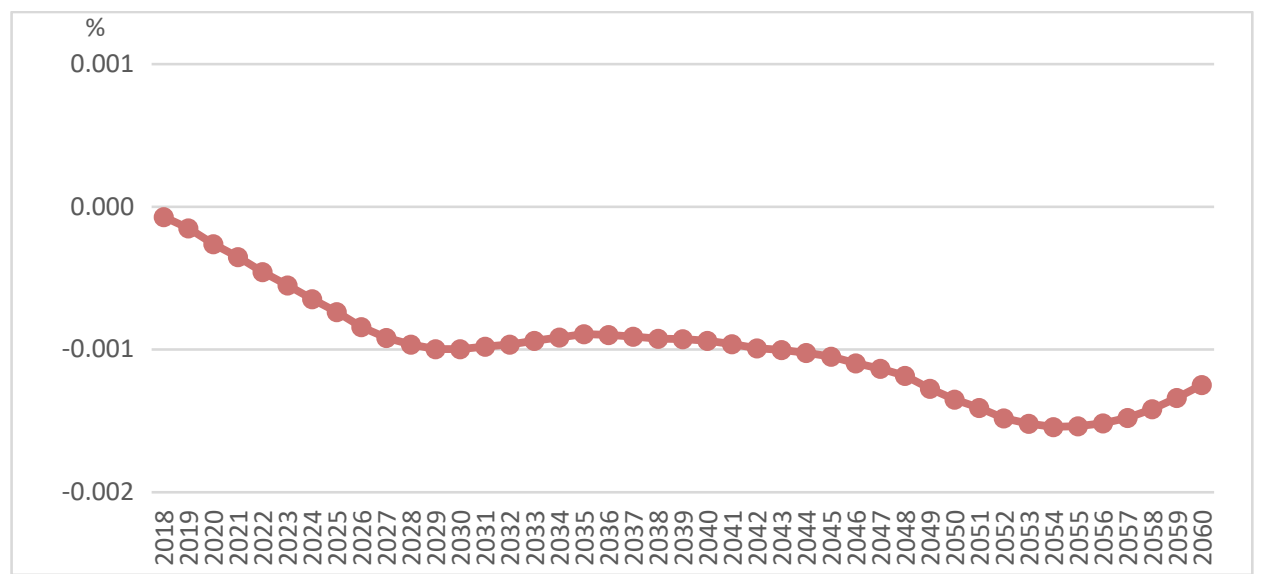

Source: author's calculations based on the SSSU data (fixed assets, number of working age persons, total population), ILO data (number of employed persons) (ILO, n.d.) and the IDBSNAN forecast (number of working age persons, total population).

Figures 15 and 16 demonstrate that the decline in the propensity to invest, resulting from the change in the demographic structure of the Ukrainian population will contribute to a decrease in the level of technical equipment of work. However, this will not have any significantly adverse effects on the labour productivity growth (the correction presented in Figure 16 is relatively minor). The total effects of the impact of the changes in tangible capital per worker on labour productivity, and thus on economic growth, are presented in Figure 17. 
Figure 17. Annual changes in the growth rate of labour productivity (and GDP per capita), resulting from changes in the technical equipment of work, caused by demographic changes in the structure of the population of Ukraine

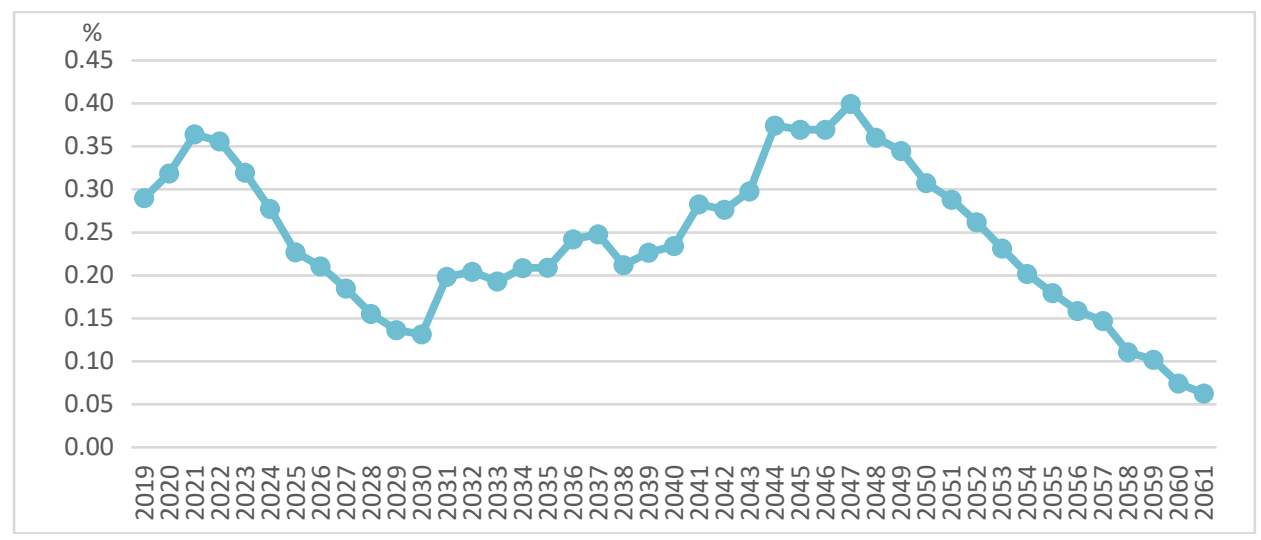

Source: author's calculations based on the SSSU data (fixed assets, number of working age persons, total population), ILO data (number of employed persons) (ILO, n.d.) and the IDBSNAN forecast (number of working age persons, total population).

As Figure 17 suggests, the negative impact on labour productivity resulting from the decline in the propensity to invest was completely offset by the positive impact from the reduction in the number of employees. However, the total impact of changes in the technical equipment of work is unevenly distributed in the analysed period. Until the beginning of the 2030s, a slowing increase in labour productivity, and thus GDP per capita, should be expected, while throughout the 2030s and 2040s an upward trend in the rate of change in labour productivity will occur, with an average annual growth equalling nearly $0.27 \%$. The late 2040 s will see another slowdown in the growth, eventually reaching about $0.07 \%$ at the end of the analysed period.

\subsubsection{Total factor productivity and labour productivity}

Total factor productivity is said to be an important factor in long-term economic growth. It is believed that the increase in the total factor productivity contributes to the greatest extent to the improvement of the standard of living of the society. When determining the total factor productivity, it is important to quantify the impact of various conditions, including demographic ones, on the total factor productivity (Florczak, 2011). The starting point is to determine the level of the total factor productivity, which can be done by transforming equation (5) and taking the logs of both sides (Feyrer, 2008): 


$$
\ln T F P_{t}=\ln y_{t}-\frac{a}{1-a} \cdot \ln \left(\frac{K}{Y}\right)_{t}-\ln h_{t}
$$

After determining the value of the total factor productivity by using the relationship described in (10), the total factor productivity should be made a function of the age structure of the employees according to the formula below, whose parameter estimates were taken from the work by Feyrer (2008) (for further details, see also Florczak (2017): ${ }^{2}$

$$
\begin{aligned}
T F P_{t} & =\exp \left[(-4.005) \cdot\left(W 1519_{t}-W 1519_{t-5}\right)+(-2.939) \cdot\left(W 2029_{t}-W 2029_{t-5}\right)+\right. \\
& +(-2.152) \cdot\left(W 3039_{t}-W 3039_{t-5}\right)+(-2.038) \cdot\left(W 5059_{t}-W 5059_{t-5}\right)+ \\
& \left.+(-2.044) \cdot\left(W 60 U P_{t}-W 60 U P_{t-5}\right)\right] \cdot T F P_{t-5}
\end{aligned}
$$

where

W1519, W2029, W3039, W5059, W60UP - shares of employees in individual age groups in total employment in period $t .^{3}$

Thus, knowing the value of the total factor productivity for 2017 (determined by using formula (10)) and when the development of the share of employees in individual age groups in total employment for 2017-2060 is calculated (see the previous parts of the article), it is possible to estimate the levels of total factor productivity in the analysed period. This will allow the assessment of the impact of changes in the demographic structure on the total factor productivity. Figure 18 shows the levels of total factor productivity normalised with respect to the values relating to 2017, while Figure 19 shows how fast the changes of this component will occur and its impact on the economic growth.

\footnotetext{
${ }^{2}$ The results regarding the impact of the age on productivity (parameters used in equation (11)) are based on the analysis of selected OECD economies.

${ }^{3}$ The fifth-order lags in equation (11) result from the fact that in the source study (see Feyrer, 2007), on the basis of which the equation was developed, changes in explanatory variables relate to 5 -year periods. Thus, the structural parameters standing next to them measure the strength of the influence over a 5-year period.
} 
Figure 18. Levels of total factor productivity caused by changes in the demographic structure of the Ukrainian population

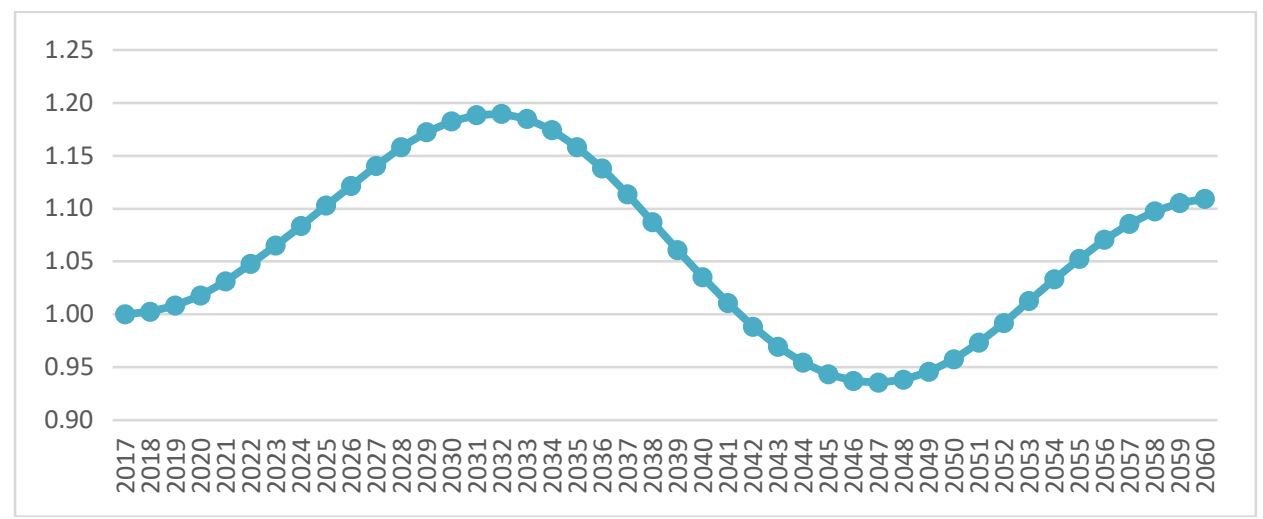

Source: author's calculations based on the SSSU data (number of the employed persons, number of working age persons), ILO data (number of employed persons) (ILO, n.d.) and the IDBSNAN forecast (number of working age persons).

Figure 19. Annual changes in the growth rate of total factor productivity, caused by changes in the demographic structure of the population of Ukraine

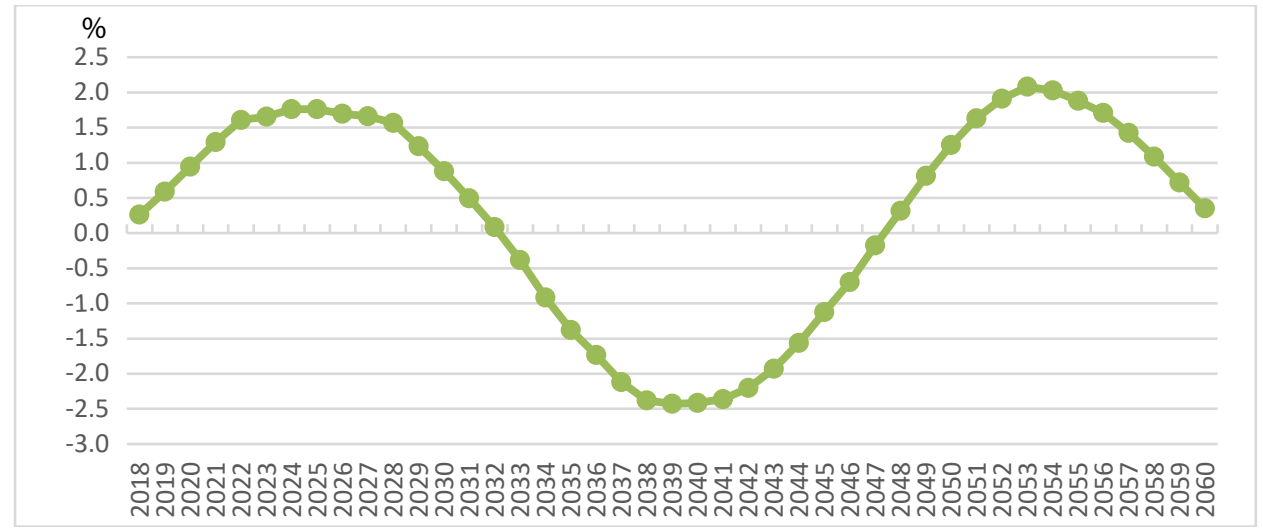

Source: author's calculations based on the SSSU data (number of the employed persons, number of working age persons), ILO data (number of employed persons) (ILO, n.d.) and the IDBSNAN forecast (number of working age persons).

As Figures 18 and 19 show, the impact of the demographic changes on the total factor productivity will not be evenly distributed within the analysed period. Up to the beginning of the 2030s, a favourable, but declining impact of changes in the demographic structure on total factor productivity, and thus on labour productivity, will be noted, whereas the 15 years that follow will be characterised by a significant, negative (average annual decrease by 1.59\%) impact of the demo-graphic conditions on economic growth. The mid-2040s will mark the beginning of a positive increase in the pace of changes in total factor productivity, caused by changes in the 
demographic structure of the society, although the average annual rate (increase by $1.33 \%$ ) will be slightly lower compared to the decline from the previous period. It should also be noted that the total factor productivity levels, determined by the demographic structure of the society, will mostly be higher in the analysed period than the level registered in 2017, with the exception of the 2040s, when the levels of the total factor productivity will be lower than those of 2017 .

\section{Cumulative effects and conclusion}

Having assessed the impact of the changes in the individual components of relationship (1) on the GDP growth rate per capita (where labour productivity has been divided into three components: human capital, technical equipment of work and total factor productivity), their combined effects can be analysed. Figure 20 shows the total effects of the impact of the changes in demographic conditions on Ukraine's economic growth by the year 2060 (being a combination of Figures 2, 6, 11,17 , and 19). On the other hand, the Table presents the average annual rates of change of all formula (1) components for selected periods within the years 20172060.

The results show that only human capital exerts a positive influence on the GDP per capita growth in the entire analysed period, but this impact, compared to the other factors, is insignificant. Moreover, the technical equipment of work factor, although minor, also has a positive impact almost throughout the entire horizon of the analysis (except for the first year). On the other hand, the age structure coefficient will exert a negative and significant impact on GDP per capita growth throughout nearly the entire analysed period (except for the first half of the 2030s). The influence of other factors on GDP per capita varies over time. The change in demographic conditions will generally have a negative impact on the effective employment rate in the years 2017-2047 (with the exception of the second half of the 2020s, when this impact will be almost neutral), and starting from the second half of the 2040s a positive impact of demographic changes on this category, thus on the economic growth, should be expected. Total factor productivity has the greatest impact on the GDP per capita growth rate in the analysed period. The impact of this factor is so substantial that the GDP per capita changes are consistent with this component's shape of changes. 
Figure 20. Annual total effects of the impact of changes in the demographic structure of the Ukrainian population on GDP per capita

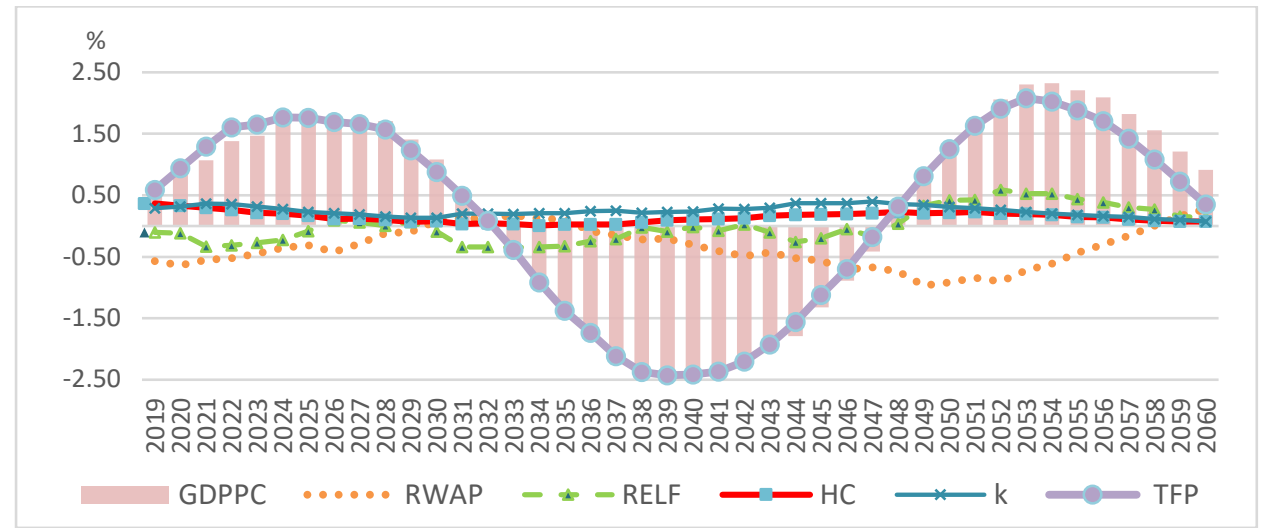

Source: author's calculations based on the SSSU data (fixed assets, number of working age persons, total population, life expectancy at birth, education), ILO (number of the employed persons, education) data (ILO, n.d.) and the IDBSNAN forecast (number of working age persons, total population, life expectancy at birth).

Table. Decomposition of the impact of demographic conditions on Ukraine's GDP per capita (average annual rates of changes, in percentages)

\begin{tabular}{|c|c|c|c|c|c|c|}
\hline \multirow[b]{2}{*}{ Years } & \multicolumn{6}{|c|}{ Category } \\
\hline & $\begin{array}{c}\text { Total factor } \\
\text { productivity } \\
\text { (TFP) }\end{array}$ & $\begin{array}{c}\text { Human } \\
\text { capital }(\mathrm{HC})\end{array}$ & $\begin{array}{l}\text { Technical } \\
\text { equipment } \\
\text { of work (k) }\end{array}$ & $\begin{array}{c}\text { Effective } \\
\text { employment } \\
\text { ratio (RELF) }\end{array}$ & $\begin{array}{c}\text { Population } \\
\text { age structure } \\
\text { (RWAP) }\end{array}$ & $\begin{array}{l}\text { GDP per } \\
\text { capita } \\
\text { (GDPPC) }\end{array}$ \\
\hline 2017-2020 ......... & 0.5963 & 0.6054 & -0.2266 & -0.0278 & -0.7343 & 0.2237 \\
\hline 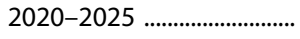 & 1.6159 & 0.2284 & 0.3087 & -0.2447 & -0.4388 & 1.4698 \\
\hline $2025-2030$. & 1.4065 & 0.0950 & 0.1637 & 0.0276 & -0.1673 & 1.5262 \\
\hline 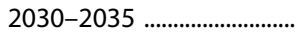 & -0.4221 & 0.0297 & 0.2026 & -0.3387 & 0.1301 & -0.3960 \\
\hline 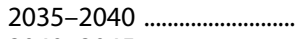 & -2.2157 & 0.0603 & 0.2324 & -0.1153 & -0.1933 & -2.2311 \\
\hline 2040-2045 & -1.8368 & 0.1549 & 0.3202 & -0.1223 & -0.4827 & -1.9656 \\
\hline 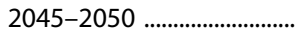 & 0.2990 & 0.2119 & 0.3564 & 0.1143 & -0.8006 & 0.1836 \\
\hline 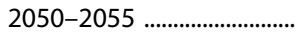 & 1.9051 & 0.1894 & 0.2324 & 0.5013 & -0.7028 & 2.1257 \\
\hline $2055-2060$ & 1.0562 & 0.0956 & 0.1185 & 0.2494 & -0.0026 & 1.5185 \\
\hline
\end{tabular}

Source: author's calculations based on the SSSU data (fixed assets, number of working age persons, total population, life expectancy at birth, education) (SSSU, n.d.), ILO data (number of employed persons, education) (ILO, n.d.) and the IDBSNAN forecast (number of working age persons, total population, life expectancy at birth).

The overall impact of the changes in the demographic conditions of the society on the long-term economic growth of Ukraine will be significant, but also significantly diversified over time. Until the beginning of the 2030s, a positive impact of demographic changes on the GDP per capita growth will be noted, with an average annual increase of nearly $1.1 \%$ and a peak observed in the middle of the second decade of the 21 st century. The next 15 years will be characterised by a strong negative impact of the demographic conditions on economic growth, with an 
average annual decline of almost $1.7 \%$ and a local extreme occurring at the turn of the 2030s and 2040s. However, in the remaining years of the analysed period, significant positive effects of the changes in the demographic structure of the society on the economic growth of Ukraine should reoccur, with an average annual increase of almost $1.6 \%$ and the greatest intensity observed at the end of the first half of the 2050s. Thus, the negative influence of the demographic changes on the economic growth of Ukraine over the analysed period should be neutralised by the positive impact that these changes are likely to entail.

Comparing these results with the analysis of the impact of demographic changes on Poland's economic growth (Florczak, 2017), numerous similarities can be observed. As in the case of Ukraine, Poland's economic growth is most strongly influenced by the total productivity of the factors of production. As in the case of Ukraine, Poland's economic growth is most strongly influenced by the total factor productivity. There is also a similarity in the pace of changes in the GDP per capita, caused by the changes of the demographic structure. In the light of these similarities, it seems that the Polish economy cannot count on a permanent and substantial labour emigration of Ukrainians in the long run, since Ukraine itself is bound to experience similar demographic problems of a nearly equal intensity and almost identical synchronisation as Poland.

\section{References}

Aksonova, I. V. (2012). Statistical Analysis of the Influence of Demographic Processes for Economic Development in Ukraine. Business Inform, (6), 86-89. http://www.business -inform.net/export_pdf/business-inform-2012-6_0-pages-86_89.pdf.

Batog, C., Crivelli, E., Ilyina, A., Jakab, Z., Lee, J., Musayev, A., Petrova, I., Scott A., Shabunina, A., Tudyka, A., Xu, X. C., \& Zhang, R. (2019). Demographic Headwinds in Central and Eastern Europe (IMF Departmental Paper No. 19/12). https:/www.imf.org/en/Publications/Departmental -Papers-Policy-Papers/Issues/2019/07/11/Demographic-Headwinds-in-Central-and-Eastern-Europe $-46992$.

Bloom, D. E., Canning, D., \& Fink, G. (2010). Implications of population ageing for economic growth. Oxford Review of Economic Policy, 26(4), 583-612. https://doi.org/10.1093/oxrep /grq038.

Bussolo, M., Koettl, J., \& Sinnott, E. (2015). Golden Aging: Prospects for Healthy, Active, and Prosperous Aging in Europe and Central Asia. Washington: World Bank. https://openknowledge .worldbank.org/handle/10986/22018.

Coleman, D., \& Rowthorn, R. (2011). Who's Afraid of Population Decline? A Critical Examination of Its Consequences. Population and Development Review, 37(s1), 217-248. https://doi.org /10.1111/j.1728-4457.2011.00385.x.

Cymbal, O., \& Iarosh, O. (2020, May 26). Ukrainskyi rynok pratsi u dzerkali ofitsiinykh ta neofitsiinykh dzherel. https://voxukraine.org/ukrayinskij-rinok-pratsi-u-dzerkali-ofitsijnih-ta -neofitsijnih-dzherel/. 
Feyrer, J. (2007). Demographics and productivity. The Review of Economics and Statistics, 89(1), 100-109. https://doi.org/10.1162/rest.89.1.100.

Feyrer, J. (2008). Aggregate Evidence on the Link Between Age Structure and Productivity. Population and Development Review, 34, 78-99. http://citeseerx.ist.psu.edu/viewdoc /download;jsessionid=259EB4445A187371450AC75976FAD182? doi=10.1.1.303.3713\&rep=rep1 \&type $=$ pdf.

Filipowicz, K., \& Tokarski, T. (2016). Zróżnicowanie wydajności pracy w Europie: na podstawie grawitacyjnego modelu wzrostu gospodarczego. In A. Nowosad \& R. Wisła (Eds.), Zróżnicowanie rozwoju współczesnej Europy (pp. 311-377). Kraków: Wydawnictwo Uniwersytetu Jagiellońskiego.

Florczak, W. (2008a). Efektywna podaż pracy a wzrost gospodarczy. Gospodarka Narodowa, 228(11-12), 21-46. https://doi.org/10.33119/GN/101300.

Florczak, W. (2008b). Kapitał ludzki w empirycznych modelach wzrostu. Ekonomista, (2), 169200.

Florczak, W. (2011). Produktywność czynników wzrostu PKB. Wiadomości Statystyczne, 56(2), 8-26. https://stat.gov.pl/czasopisma/wiadomosci-statystyczne/archiwum/.

Florczak, W. (2017). Wpływ starzejącego się społeczeństwa na długookresowy wzrost gospodarczy Polski do roku 2050. Gospodarka Narodowa, 291(5), 73-104. https://doi.org/10.33119/GN /100743.

Florczak, W., \& Przybyliński, M. (2016). Zmiany w liczebności i strukturze populacji a rozwój społeczno-ekonomiczny. Studia Ekonomiczne, 3(90), 396-422. https://inepan.pl/wp-content /uploads/2016/08/SE_2016_3_Florczak.pdf.

Florczak, W., Przybyliński, M., Świeczewska, I., Tomaszewicz, Ł., \& Trębska, J. (2018). Wybrane zjawiska i procesy wpływające na rozwój polskiej gospodarki w pierwszej połowie XXI wieku. Projekcje na podstawie systemu modeli makroekonomicznych. Łódź: Wydawnictwo Uniwersytetu Łódzkiego. https://wydawnictwo.uni.lodz.pl/wp-content/uploads/2019/01/Florczak-i-in._Wybrane -zjawiska-.pdf.

Geyets, V. M. (2011). The consequences of demographic challenges for economic growth in Ukraine. Demography and social economy, (1), 3-23. https://doi.org/10.15407/dse2011.01.

International Labour Organization. (n.d.). ILO Data Explorer [Data sets]. Retrieved February 3, 2021, from https://www.ilo.org/shinyapps/bulkexplorer9/.

Jong-Won, Y., Jinill, K., \& Jungjin, L. (2014). Impact of Demographic Changes on Inflation and the Macroeconomy (IMF Working Paper No. 14/210). https://www.imf.org/external/pubs/ft /wp/2014/wp14210.pdf.

Kudlak, V. (2019). Dynamics of dymographic processes in Ukraine and its impact on national economy. Galician economic journal (Tern.), 4(59), 98-104. https://doi.org/10.33108/galicianvisnyk _tntu2019.04.098.

Kupets, O. (2014). Labor Market Challenges of an Aging and Shrinking Population in Ukraine. Journal of Comparative Economic Studies, 9, 99-134. http://www.ces.kier.kyoto-u.ac.jp/jces 109_jces_2014/08_Kupets.pdf.

Liu, Y., Xiao, H., \& Zhu, S. (2013). Population Aging, Saving Rates and Long-term Economic Growth in China: Based on Dynamic GGE Model. Annual Conference on Global Economic 
Analysis, Shanghai. https://www.gtap.agecon.purdue.edu/resources/res_display.asp?RecordID $=4126$.

Maksymenko, S. (2009). Fertility, Money Holdings, and Economic Growth: Evidence from Ukraine. Comparative Economic Studies, 51(1), 75-99. https://doi.org/10.1057/ces.2008.45.

Mączyńska, E. (2010). Przełom cywilizacyjny a wzrost gospodarczy. Niedoceniane aspekty demograficzne. In A. Potrykowska \& E. Orzełek (Eds.), Biuletyn nr 55 (pp. 18-28). Warszawa: Rządowa Rada Ludnościowa. https://stat.gov.pl/cps/rde/xbcr/bip/BIP_biuletyn55.pdf.

Ptoukha Institute for Demography and Social Studies of the National Academy of Sciences of Ukraine. (2014). National Population Projections: Revision. Retrieved February 3, 2021, from https://idss.org.ua/forecasts/nation_pop_proj_en.

Romanukha, O. M. (2016). Social-economic consequences of Ukrainian population ageing. Scientific Bulletin of KSU. Series Economic Sciences, 17(3), 91-94. http://www.ej.kherson.ua /journal/economic_17/3/25.pdf.

Rovný, P., Moroz, S., Palkovič, J., \& Horská, E. (2021). Impact of Demographic Structure on Economic Development of Ukrainian Coastal Regions. Sustainability, 13(4), 1-19. https://doi.org/10.3390/su13041798.

Stoychik, T. (2018). Forming the modern labour market: analysis of request and proposal of the working force. Professional Pedagogics, (17), 101-105. https://doi.org/10.32835/2223-5752.2018 .17.101-105.

Vakhitova, G., \& Coupe, T. (2013). The Relations between Education and Migration in Ukraine. Budapest: International Labour Organization. http://legacy.iza.org/en/papers/7990_19032014.pdf.

Wasilewska, E., \& Pietrych, Ł. (2018). Starzenie się społeczeństwa a wzrost gospodarczy w krajach Unii Europejskiej. Zeszyty Naukowe Szkoły Głównej Gospodarstwa Wiejskiego w Warszawie. Problemy Rolnictwa Światowego, 18(4), 481-492. http://sj.wne.sggw.pl/pdf/PRS_2018_T18(33) _n4.pdf.

Wößmann, L. (2003). Specifying human capital. Journal of Economic Surveys, 17(3), 239-270. https://doi.org/10.1111/1467-6419.00195.

Zoidze, D. R. (2013). Modern labour market: dismissal of employees as a factor of structural discrepancy between supply and demand. Problems of Economy, (2), 59-65. https://www.problecon.com/export_pdf/problems-of-economy-2013-2_0-pages-59_65.pdf. 